Collection: 3rd International Elm Conference, Florence (Italy - 2013)

"The elms after 100 years of Dutch Elm disease"

Guest Editors: A. Santini, L. Ghelardini, E. Collin, A. Solla, J. Brunet, M. Faccoli, A. Scala, S. De Vries, J. Buiteveld

\title{
Seven Ulmus minor clones tolerant to Ophiostoma novo-ulmi registered as forest reproductive material in Spain
}

\author{
Juan Antonio Martín ${ }^{(1)}$, Alejandro Solla ${ }^{(2)}$, Martin Venturas ${ }^{(1)}$, Carmen \\ Collada $^{(1)}$, Jorge Domínguez ${ }^{(1)}$, Eva Miranda ${ }^{(1)}$, Pablo Fuentes ${ }^{(3)}$, \\ Margarita Burón ${ }^{(1)}$, Salustiano Iglesias ${ }^{(4)}$, Luis Gil ${ }^{(1)}$
}

The Spanish elm programme began in 1986 in response to the devastating impact of Dutch elm disease on natural elm stands and urban trees. Its main objectives were to conserve remaining genetic resources and select and breed tolerant native elm genotypes. After 27 years of work conducting susceptibility trials on thousands of elm genotypes, the first seven tolerant Ulmus minor trees are now being registered by the Spanish Environmental Administration. This paper presents the results of the susceptibility tests on these clones and their distinctive genetic, morphological and phenological features. In all susceptibility trials the commercial "Sapporo Autumn Gold" clone, which is highly tolerant to 0 . novo-ulmi, was used as a control. The registered clones were named "Ademuz", "Dehesa de la Villa", "Majadahonda", "Toledo", "Dehesa de Amaniel", "Retiro" and "Fuente Umbría". The most tolerant clone was "Dehesa de Amaniel", as its wilting values were below 5\% during the two consecutive inoculation trials performed in Madrid. "Fuente Umbría", tested over four consecutive years in Guadalajara and Palencia, was the Spanish clone with the most reliable tolerance level to 0 . novo-ulmi. The "Ademuz" and "Majadahonda" clones had the highest ornamental scores and are promising trees for use in urban environments and tree breeding for ornamental quality. These two genotypes showed a later bud burst phenology than the other $U$. minor clones, demonstrating suitability to areas with late frost events. The Spanish programme aims to substantially increase the range of tolerant native elms through new selections and crossings to gain a better understanding of the genetic basis of resistance.

Keywords: Dutch Elm Disease, Breeding, Plant Release, Resistance, Invasive Species

\section{Introduction}

In the first half of the $20^{\text {th }}$ century, the first Dutch elm disease (DED) pandemic caused a massive loss of elms in Europe and North America. The much more aggressive $O$. novo-ulmi Brasier took the place of the causal agent, Ophiostoma ulmi (Buisman) Nannf., in the second half of the century. The second pathogen has caused the disappearance of adult elms in many European and North American locations (Brasier \& Kirk 2010) O. novo-ulmi is almost impossible to control through chemical, biological or silvicultural methods due to its high virulence and highly effective transmission via small beetles of the Scolytus and Hylorgopinus genera (Webber 2000). Tolerant elm genotype selection and breeding has been the most successful strategy for elm recovery, particularly in ur- ban environments (Santini et al. 2004, 2011, Solla et al. 2005a, 2014). The Spanish elm breeding and conservation programme began in 1986 as the result of an agreement between the Spanish Environmental Administration and the Technical University of Madrid School of Forestry Engineering. Its two main objectives were to conserve remaining elm genetic resources and to transmit their variability to future generations of tolerant elms obtained through breeding; i.e., hybridisation of selected progenitors (native or tolerant Asian elms) to obtain tolerant trees with the appearance of native elm species.

The first elm breeding programme began in the Netherlands in 1928 (Heybroek 1993) and was followed by several programmes in the United States and various European countries (Mittempergher \& Santini 2004). $\square$ (1) ETSI Montes, Universidad Politécnica de Madrid, Ciudad Universitaria s/n, E-28040 Madrid (Spain); (2) Ingeniería Forestal y del Medio Natural, Universidad de Extremadura, Avenida Virgen del Puerto 2, E-10600 Plasencia (Spain); (3) Institute of Evolutionary Biology, The University of Edinburgh, West Mains Rd., Edinburgh EH9 9JT (United Kingdom); (4) Dirección General de Desarrollo Rural y Política Forestal, Ministerio de Medio Ambiente y Medio Rural y Marino, c/ Ríos Rosas 24, E-28003 Madrid (Spain)

\section{@ Luis Gil (luis.gil@upm.es)}

Received: Dec 30, 2013 - Accepted: May 21, 2014

Citation: Martín JA, Solla A, Venturas M, Collada C, Domínguez J, Miranda E, Fuentes P, Burón M, Iglesias S, Gil L, 2015. Seven Ulmus minor clones tolerant to Ophiostoma novo-ulmi registered as forest reproductive material in Spain. iForest 8: 172-180 [online 2014-08-13] URL: http://www.

sisef.it/iforest/contents/?id=ifor1224-008

\section{Communicated by: Alberto Santini}

Asian elms, including Ulmus pumila, $U$. chenmoui, U. davidiana var. japonica and $U$. wallichiana, have been the main sources of resistance in the Dutch, American and Italian elm breeding programmes (Heybroek 1993, Smalley \& Guries 2000, Santini et al. 2011, Buiteveld et al. 2014). As a result of crossing these species with native elms, a wide range of hybrid clones of varying tolerance levels and genetic backgrounds is now available on the market. The Spanish programme took advantage of the knowledge, methodologies and plant materials previously developed by the Dutch and Italian programmes. In the first 14 years, $U$. pumila was used as the main source of resistance, giving rise to 10 crossings tolerant to $O$. novo-ulmi (Solla et al. 2000). The tolerance of these crossings was tested in clone replicates $(N>16)$ over several years at various locations, and clone adaptation to different environments in Spain was evaluated. Five crossings with Asian background were recently selected to be released onto the market for ornamental use.

In the 1990s the Spanish programme included some native elms, mainly U. minor, in the $O$. novo-ulmi susceptibility trials. In the following decade the programme focused mainly on selecting native elms. This new strategy complied with European and Spanish legislation governing the quality and genetic background of forest reproductive materials for production and marketing. In the European Union, forest reproductive materials are governed by Council Directive 
1999/105/CE, and Annex I of the directive lists the permitted forest species. Although Ulmus species are not included in Annex I, Article 3.2 of the directive allows particular Member States to add to the list. In Spain, several regions expressed the need to certify the plant origin and genetic quality of some forest species not included in Annex I that are traditionally used in reforestation programmes. As a result, Annex XII of Spanish Royal Decree-Law 289/2003 listed 24 additional forest species, including U. glabra and $U$. minor (Iglesias 2005). The major spread of $U$. pumila in Spain and its extensive hybridisation with the native $U$. minor (Cogolludo-Agustín et al. 2000) led to conservation concerns for the native species. To preserve the genetic integrity of the Spanish elms, artificial hybrids in the genus Ulmus were not included in Annex XII of Royal Decree-Law $289 / 2003$. This means that hybrids with Asian background cannot be marketed for forest use in Spain, although they can be used for urban planting.

Progress in selecting elms was slow due to the long periods required to propagate trees and evaluate their tolerance with a scientifically sound base, as plant material needs to be at least four years old (Solla et al. 2005c). In the case of selecting pure U. minor material, a further difficulty was the very limited number of native elms exhibiting some degree of tolerance to $O$. novo-ulmi, which was around $0.5 \%$ in comparison to $2-5 \%$ for hybrids with Asian background (unpublished results). Fortunately, susceptibility trials performed in the last 10 years provided some native individuals with low leaf wilting values. After 27 years of activity, the Spanish programme continues to breed and conserve Spanish elms with the ultimate goal of recovering their forest and ornamental uses.

Native elms can be registered by the Environmental Administration as "qualified forest reproductive material" when they show low $(0-30 \%)$ crown wilting or symptoms similar to the tolerant "Sapporo Autumn Gold" clone after two consecutive years of artificial inoculation with $O$. novo-ulmi. At least six replicates of the tested clone must be inoculated. Replicates are grown in a plot in which a susceptible control clone has to exhibit more than $70 \%$ wilting symptoms. When a tested clone is registered, it can be propagated, marketed and used for forest purposes. The "qualified" category is provisional and after 10 years it becomes "controlled material" and acquires a permanent category (Iglesias 2005). Before clones are registered as "controlled material", they must meet the same requirements as "qualified material" when tested at a second location. This paper reports the selection and the features of the first $U$. minor clones registered for forest use in Spain. The potential use of these clones and the future of the Spanish breeding programme are discussed.

\section{Material and methods}

\section{Plant material}

From 1990 to 2002, plant material was propagated from trees selected during surveys of adult elms in natural forests, rural areas, parks, and other urban environments in Spain (Tab. 1). The main selection criterion was good sanitary status, i.e., putative tolerance if trees had survived in a DED affected area. Trees were propagated using seeds, root cuttings and grafts (Tab. 1). In the case of seed propagation, seedlings selected for their tolerance to $O$. novo-ulmi were propagated by hardwood cuttings and at least six ramets per seedling were obtained. This procedure was used for the "Dehesa de Amaniel", "Retiro", "Toledo", and "Fuente Umbría" clones.

Ramets of the seven clones were planted with 157 other elm clones in five different inoculation plots in Spain (Tab. 1), under a
Mediterranean phytoclimate (Allué-Andrade 1990). All clones except "Fuente Umbría" were planted in Puerta de Hierro Forest Breeding Center, Madrid (40 $27^{\prime} 24^{\prime \prime} \mathrm{N} ; 3^{\circ}$ $45^{\prime} 0^{\prime \prime} \mathrm{W} ; 600 \mathrm{~m}$ a.s.l.). This location has an average annual rainfall of $397 \mathrm{~mm}$ and an average annual temperature of $14^{\circ} \mathrm{C}$. "Fuente Umbría" ramets were planted in El Serranillo Forest Breeding Center (Guadalajara $40^{\circ} 40^{\prime} 13^{\prime \prime} \mathrm{N}$; $3^{\circ} 9^{\prime} 39^{\prime \prime} \mathrm{W} ; 685$ m a.s.l.; 457 $\mathrm{mm}, 13.5^{\circ} \mathrm{C}$ ) and Calabazanos Forest Health

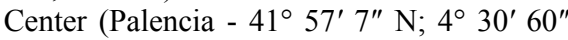
W; $739 \mathrm{~m}$ a.s.1.; $412 \mathrm{~mm}, 11.7^{\circ} \mathrm{C}$ ).

Plots were designed in two blocks, with random experimental units of three to four ramets per block. Spacing in Puerta de Hierro and El Serranillo was 0.5 to $1 \mathrm{~m}$ between plants and 1 to $1.5 \mathrm{~m}$ between rows. In Calabazanos spacing was $5 \times 5 \mathrm{~m}$. To avoid side effects, a tree border line surrounded all plots. Plants were watered in spring and summer to ensure growth. Their main stems were fastened to supports to avoid wind shake. "Sapporo Autumn Gold", highly tolerant to O. novo-ulmi (Smalley \& Lester 1973), and UPM089, a Spanish U. minor clone classified by the Spanish elm breeding programme as very susceptible to $O$. novoulmi, were used as control clones. At least six replicates of each control were included in each inoculation plot.

\section{Inoculations}

Local strains of $O$. novo-ulmi were used to evaluate the tolerance level of the clones (Tab. 1). Strains NA-PE, CU-HU and ZBU1 were isolated form DED-infected trees in Peralta (Navarra), Huelves (Cuenca) and Bubierca (Zaragoza), respectively. Strains NA-PE and CU-HU were isolated in 2002 and Z-BU1 was isolated in 2009. Inoculations were performed at the end of April or beginning of May, depending on the plant phenological stage, about 15-30 days after full leaf development. This is the time U. mi-

Tab. 1 - Plant material specifications. (a) R: root cutting; G: graft; S: seed; (b) numbers in brackets indicate the year of inoculation.

\begin{tabular}{|c|c|c|c|c|c|c|c|c|}
\hline \multirow[b]{2}{*}{ Clone } & \multirow{2}{*}{$\begin{array}{l}\text { Origin } \\
\text { in Spain }\end{array}$} & \multicolumn{5}{|c|}{ Initial propagation } & \multicolumn{2}{|l|}{ Inoculation test } \\
\hline & & Type $^{\mathrm{a}}$ & Year & Plot & $\mathbf{N}$ & Years & $\begin{array}{l}\text { Location } \\
\text { in Spain }\end{array}$ & $\begin{array}{c}\text { O. novo-ulmi } \\
\text { ssp. americana } \text { strain }^{\mathrm{b}}\end{array}$ \\
\hline Ademuz & $\begin{array}{l}\text { Valencia } \\
40^{\circ} 4^{\prime} 52^{\prime \prime} \mathrm{N}, 1^{\circ} 16^{\prime} 55^{\prime \prime} \mathrm{W}\end{array}$ & $\mathrm{R}$ & 1996 & XXIV & 10 & $\begin{array}{l}2008 \\
2009\end{array}$ & Puerta de Hierro & $\begin{array}{l}\text { NA-PE (2008), } \\
\text { CU-HU (2009) }\end{array}$ \\
\hline $\begin{array}{l}\text { Dehesa } \\
\text { de la Villa }\end{array}$ & $\begin{array}{l}\text { Madrid } \\
40^{\circ} 27^{\prime} 29^{\prime \prime} \mathrm{N}, 3^{\circ} 44^{\prime} 00^{\prime \prime} \mathrm{W}\end{array}$ & $\mathrm{R}$ & 1990 & $\mathrm{XXV}$ & 10 & $\begin{array}{l}2009 \\
2010\end{array}$ & Puerta de Hierro & CU-HU \\
\hline Majadahonda & $\begin{array}{l}\text { Madrid } \\
40^{\circ} 28^{\prime} 90^{\prime \prime} \mathrm{N}, 3^{\circ} 52^{\prime} 19^{\prime \prime} \mathrm{W}\end{array}$ & G & 1993 & XXIV & 6 & $\begin{array}{l}2008 \\
2009\end{array}$ & Puerta de Hierro & $\begin{array}{l}\text { NA-PE (2008), } \\
\text { CU-HU (2009) }\end{array}$ \\
\hline Toledo & $\begin{array}{l}\text { Toledo } \\
39^{\circ} 51^{\prime} 51^{\prime \prime} \mathrm{N}, 4^{\circ} 1^{\prime} 30^{\prime \prime} \mathrm{W}\end{array}$ & $\mathrm{S}$ & 1999 & $\mathrm{XXX}$ & 7 & $\begin{array}{l}2011 \\
2012\end{array}$ & Puerta de Hierro & Z-BU1 \\
\hline $\begin{array}{l}\text { Dehesa } \\
\text { de Amaniel }\end{array}$ & $\begin{array}{l}\text { Madrid } \\
40^{\circ} 27^{\prime} 37^{\prime \prime} \mathrm{N}, 3^{\circ} 43^{\prime} 17^{\prime \prime} \mathrm{W}\end{array}$ & $\mathrm{S}$ & 1999 & $\mathrm{XXX}$ & 12 & $\begin{array}{l}2011 \\
2012\end{array}$ & Puerta de Hierro & Z-BU1 \\
\hline Retiro & $\begin{array}{l}\text { Madrid } \\
40^{\circ} 24^{\prime} 56^{\prime \prime} \mathrm{N}, 3^{\circ} 41^{\prime} 10^{\prime \prime} \mathrm{W}\end{array}$ & $\mathrm{S}$ & 2002 & $\mathrm{XXX}$ & 7 & $\begin{array}{l}2011 \\
2012\end{array}$ & Puerta de Hierro & Z-BU1 \\
\hline Fuente Umbría & $\begin{array}{l}\text { Valencia } \\
39^{\circ} 25^{\prime} 23^{\prime \prime} \mathrm{N}, 0^{\circ} 56^{\prime} 46^{\prime \prime} \mathrm{W}\end{array}$ & $\mathrm{S}$ & 1995 & $\mathrm{~V}$ and $\mathrm{A}$ & $>10$ & $\begin{array}{l}2010- \\
2013\end{array}$ & $\begin{array}{l}\text { El Serranillo and } \\
\text { Calabazanos }\end{array}$ & $\begin{array}{c}\text { CU-HU (2010), } \\
\text { Z-BU1 (2011-2013) }\end{array}$ \\
\hline
\end{tabular}


nor takes to reach its susceptibility peak to O. novo-ulmi in Madrid (Solla et al. 2005b).

A bud-cell suspension of the pathogen was prepared by adding $2 \times 2 \mathrm{~mm}$ plugs from the edge of 7-day-old cultures on malt extract agar to $50 \mathrm{ml}$ Tchernoff's liquid medium (Tchernoff 1965) in sterile Erlenmeyer flasks, followed by shaking in the dark for four days at room temperature. Spore suspensions were centrifuged at $50 \times \mathrm{g}$ for 20 min to eliminate the medium and then suspended in sterile distilled water. Pathogen inoculation was performed by inserting 0.1 $\mathrm{ml}$ of the spore suspension at $10^{6}$ spores $\mathrm{ml}^{-1}$ into an incision made in the trunk base with a razor blade, allowing the suspension to be absorbed by the sap flow. The elms were at least four years old and $1.5 \mathrm{~m}$ in height, to obtain maximum disease symptoms (Solla et al. 2005c). Disease development was evaluated by three independent observers who recorded the percentage of wilting leaves in the crown at 30,60 and 120 days post inoculation (dpi).

\section{Molecular characterization}

In the marketing of forest reproductive material, characterization and traceability of trees are of pivotal importance. Various techniques using molecular markers are efficient tools for this purpose. Genetic characterization of the seven $U$. minor clones was performed at two levels. Trees were analyzed firstly with chloroplast DNA markers to determine the lineages of the individuals selected, and secondly with nuclear DNA markers to quantify genotypic diversity (Gil et al 2004).

For the lineage study, two chloroplast markers were used. One corresponds to the chloroplast fragment SFm and was developed from the sequence of the SFm fragment to differentiate the $U$. minor lineages in Spain (Collada et al., unpublished data). The other marker corresponds to microsatellite ccmp2, which was developed for tobacco (Weising \& Gardner 1999) and transferred to $U$. minor to enable differentiation of variants within lineages.

For the genetic description, 12 nuclear microsatellites were selected. Four of these were described in U. minor (Ulmi1-98, Ulmi1165, Ulmi2-16 and Ulmi2-20 - Collada et al. 2004), three were transferred from $U$. laevis (Ulm2, Ulm3 and Ulm8 - Whiteley et al. 2003) and five were transferred from $U$. rubra (UR 123, UR 141, UR 153, UR 158 and UR 159 - Zalapa et al. 2008).

Leaves from at least two individuals for each selected clone were collected, labeled and stored in silica gel. After DNA extraction, $2.5 \mathrm{ng} \mu \mathrm{l}^{-1}$ dilutions were used in amplification reactions conducted following the literature (Weising \& Gardner 1999, Collada et al. 2004, Whiteley et al. 2003, Zalapa et al. 2008).
Tree morphology and phenology assessments

Clones were morphologically described following specific literature (Richens 1955, Jeffers \& Richens 1970, Ipinza 1990). Quantitative data on subdistal leaves of new shoots were measured on four leaves per tree. The parameters measured are shown in Fig. 1. The number of nerve pairs, total number of main teeth per leaf, and type of leaf margin serration (simple, double or triple) were also determined.

Height growth of each clone was assessed in Puerta de Hierro Forest Breeding Center (Madrid), as well as ornamental qualities of trees such as growth habit and branching (erect, spreading, or pendulous), leaf density (abundance of leaves per crown volume, estimated as high, medium or low), crown shape (conical, spindle, globular or irregular) and leaf size. The ornamental value of each clone was quantified on a scale from 1 to 5 , where 5 corresponded to the most frequent features of Spanish U. minor according to the clone collection $(\mathrm{N}=363)$ held at Puerta de Hierro Forest Breeding Center (i.e., erect branching, globular-spindle crown, medium-high leaf density, leaf size of about $50 \mathrm{~mm}$ length and $30 \mathrm{~mm}$ width) and 1 corresponded to unusual $U$. minor features. The presence of corky tissue was also recorded but not considered for ornamental evaluation. After four independent observers had assessed ornamental quality, the average value was calculated.

The unfolding of elm leaf buds was characterized in 2011 using the methodology described by Santini et al. (2005). Leaf phenology is divided into five stages from bud formation to complete leaf expansion: phase 1: dormant buds; phase 2: swelling buds but with closed flakes; phase 3: flakes open and the first leaf ends are visible in the apex of the buds; phase 4: the ends of all the leaves are visible but the leaves are not expanded; Phase 5: two or more leaves are fully expanded. To compare leaf phenology between genotypes, these stages were grouped into three classes: dormancy (phases 1 and 2), bud break (phases 3 and 4), and leaf expanded (phase 5).

\section{Statistical analysis}

For each inoculation plot and year, wilting percentages at 30,60 and 120 dpi were analyzed using repeated measures ANOVA, considering time since inoculation, block, and genotype as the main factors and tree height as a covariate. Fisher's least significant difference (LSD) test was applied to compare average wilting values (least square means of wilting percentages at 30,60 and $120 \mathrm{dpi})$ between clones $(P<0.05)$. Analyses were performed using the STATISTICA v. 7.0 package (StatSoft Inc., Tulsa, OK, USA).

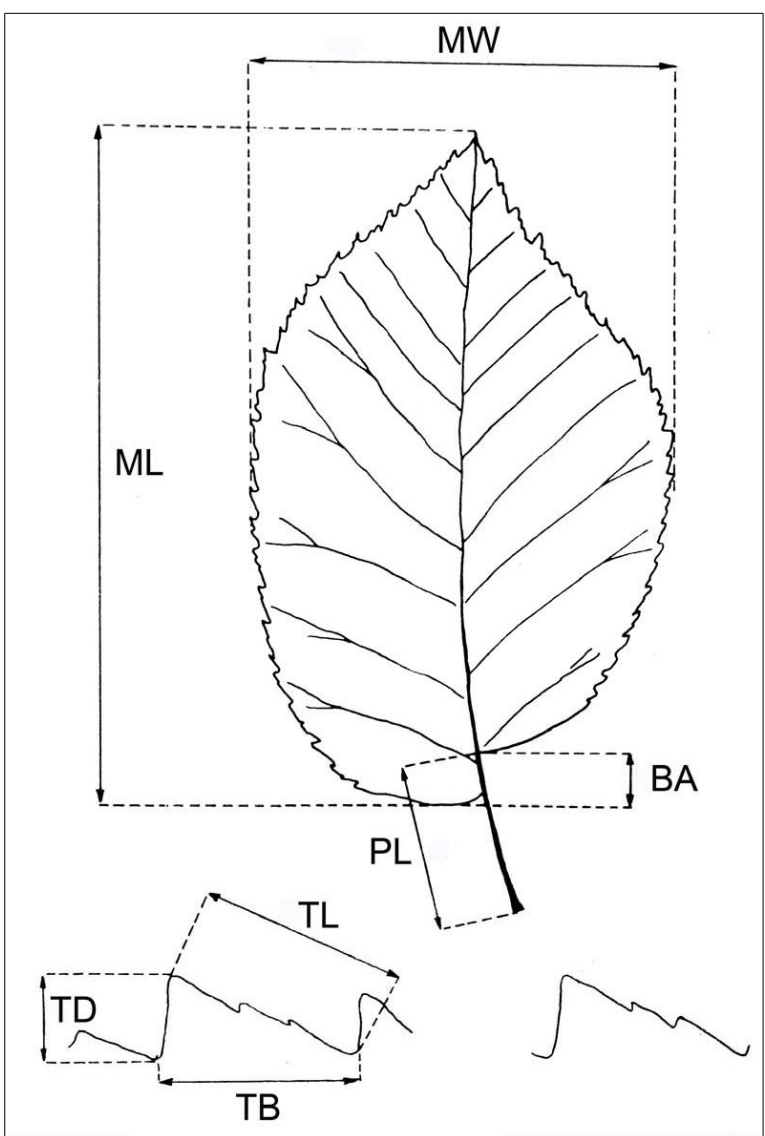

Fig. 1 - Foliar parameters measured to describe the Ulmus minor clones. (MW): maximum foliar width; (ML): maximum foliar length; (BA): basal asymmetry; (PL): petiole length; (TD): tooth depth; (TL): tooth length; (TB): tooth breadth. 
Tab. 2 - Results (p-values) of repeated measures ANOVA of the wilting values shown by elm trees at 30,60 and 120 dpi (repeated variable) considering time since inoculation, genotype, block, and genotype x block interaction as factors, and plant height as a covariate. (a): The plot had one block.

\begin{tabular}{|c|c|c|c|c|c|c|}
\hline \multirow{2}{*}{$\begin{array}{c}\text { Inoculation } \\
\text { year }\end{array}$} & \multirow[b]{2}{*}{ Plot } & \multicolumn{5}{|c|}{ Source of variation } \\
\hline & & Time dpi & $\begin{array}{l}\text { Genotype } \\
\text { (G) }\end{array}$ & Block (B) & $\mathbf{G} \times \mathbf{B}$ & $\begin{array}{l}\text { Plant } \\
\text { height }\end{array}$ \\
\hline 2008 & XXIV & $<0.001$ & $<0.001$ & $<0.001$ & 0.001 & 0.708 \\
\hline 2009 & XXIV & 0.15 & $<0.001$ & 0.029 & 0.65 & 0.928 \\
\hline 2009 & XXV & 0.002 & $<0.001$ & 0.032 & $<0.001$ & 0.078 \\
\hline 2010 & XXV & $<0.001$ & $<0.001$ & 0.064 & $<0.001$ & 0.513 \\
\hline 2010 & $\mathrm{~V}$ & $<0.001$ & $<0.001$ & 0.163 & 0.751 & 0.951 \\
\hline 2011 & V & $<0.001$ & $<0.001$ & 0.185 & 0.572 & 0.839 \\
\hline 2011 & XXX & $<0.001$ & $<0.001$ & 0.001 & $<0.001$ & $<0.001$ \\
\hline 2012 & XXX & $<0.001$ & $<0.001$ & 0.068 & 0.01 & 0.91 \\
\hline 2012 & $\mathrm{~A}^{\mathrm{a}}$ & $<0.001$ & $<0.001$ & - & - & 0.623 \\
\hline 2013 & $\mathrm{~A}^{\mathrm{a}}$ & 0.001 & $<0.001$ & - & - & 0.086 \\
\hline
\end{tabular}

\section{Results and Discussion}

Seven $U$. minor clones were selected for their tolerance to $O$. novo-ulmi in various susceptibility tests conducted in Spain. The results of the repeated measures ANOVA of leaf wilting at 30,60 and 120 dpi (Tab. 2) showed that genotype was a highly significant factor, block was an important source of variation in some plots (XXIV, XXV and $\mathrm{XXX}$ ), and plant height was not a significant effect, except in 2011 in plot XXX. The ef- fect of time since inoculation on the wilting values observed was significant in all susceptibility tests, except in 2009 in plot XXIV (Tab. 2). The highest wilting values were recorded at $60 \mathrm{dpi}$ (data not shown). After pathogen inoculation, the seven clones showed leaf wilting values similar to or lower than "Sapporo Autumn Gold" (Fig. 2). In all tests, the susceptible control clone UPM089 showed wilting values above $70 \%$, confirming the virulence of the isolates used and the correct inoculation methodology. The most tolerant clone was "Dehesa de Amaniel", with wilting values below $5 \%$ during the two consecutive inoculation trials performed in Madrid.

Six clones were tested at one location (Madrid), but the "Fuente Umbría" clone was tested over four consecutive years in Guadalajara and Palencia (Fig. 2d). These two locations are $280 \mathrm{~km}$ apart and have different climate conditions. "Fuente Umbría" should therefore be regarded as the Spanish clone with the most reliable tolerance level to $O$. novo-ulmi. The six other clones will need to pass a second inoculation test under a different environment from Madrid before they can be registered as controlled material. Given the availability of ramets from this material, the second test will be performed in 2016 for the "Ademuz", "Dehesa de la Villa", "Dehesa de Amaniel", "Retiro" and "Toledo" clones, and in 2018 for the "Majadahonda" clone.

Environmental conditions can strongly influence elm susceptibility to $O$. novo-ulmi (Smalley 1963, Sutherland et al. 1997, Solla \& Gil 2002, Martín et al. 2010a). Use of registered material in areas with a similar environment to the area of the susceptibility test is therefore highly recommended. The seven clones performed well during the inoculation years under the environmental conditions described, but their long-term tolerance to pos-
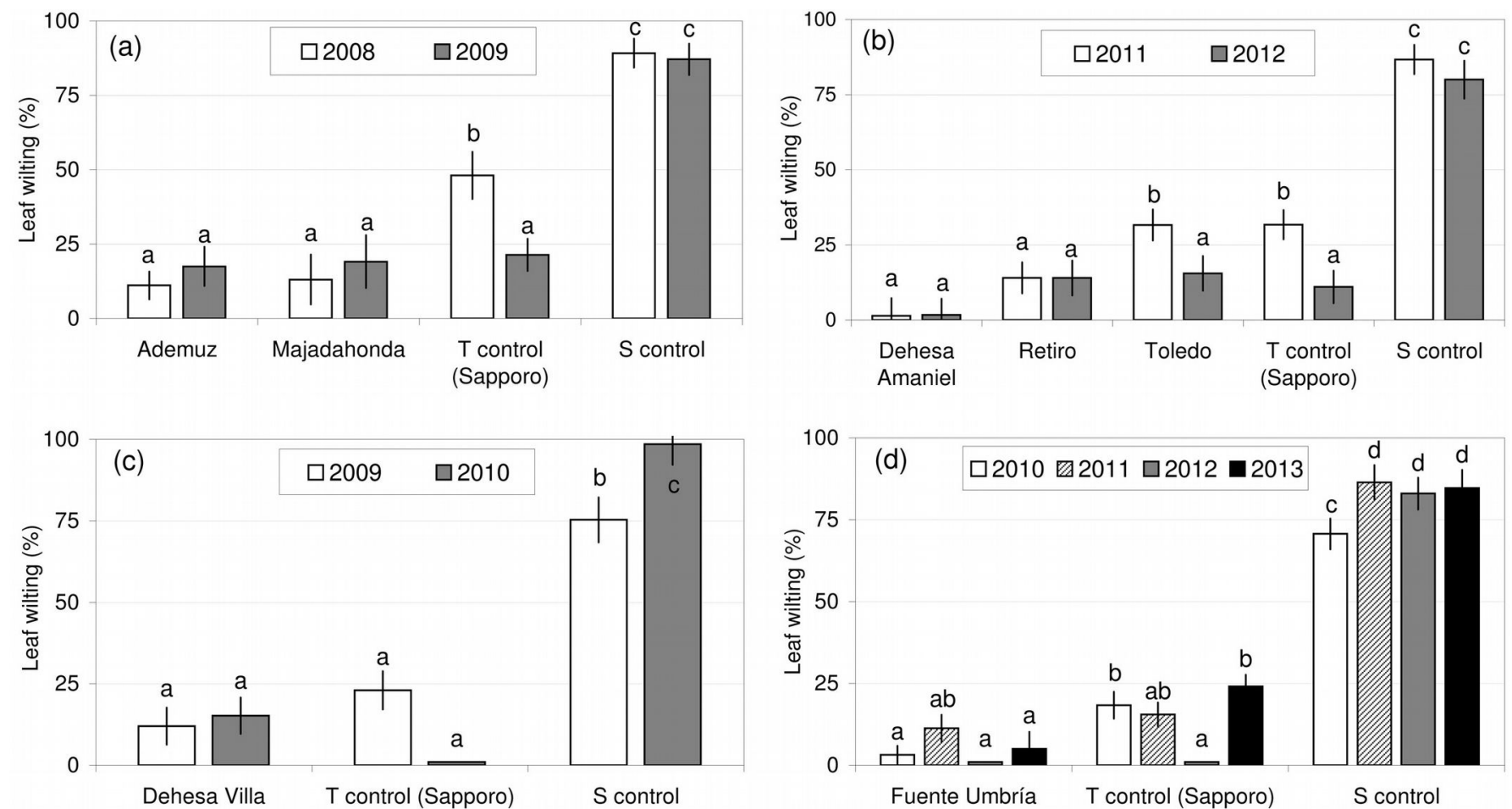

Fig. 2 - Susceptibility of the seven Ulmus minor clones (least squares means of wilting percentages at 30, 60 and 120 dpi) after tests performed at various experimental plots in Spain. (a) "Ademuz" and "Majadahonda" clones, tested in Puerta de Hierro Forest Breeding Center, Madrid; (b) "Dehesa de Amaniel", "Retiro" and "Toledo" clones, tested in Puerta de Hierro; (c) "Dehesa de la Villa" clone, tested in Puerta de Hierro; (d) "Fuente Umbría" clone, tested in 2010 and 2011 in El Serranillo Forest Breeding Center, Guadalajara, and in 2012 and 2013 in Calabazanos Forest Health Centre, Palencia. (T): tolerant; (S): susceptible. 
Tab. 3 - Morphological description of the seven Ulmus minor clones. Numbers in brackets indicate range values. (a): on a scale from 1 to 5 , where $5=$ most attractive (typical $U$. minor traits), $1=$ least attractive (unusual $U$. minor traits).

\begin{tabular}{|c|c|c|c|c|c|c|c|}
\hline \multirow[b]{2}{*}{ Feature } & \multicolumn{7}{|c|}{ Clone } \\
\hline & Ademuz & $\begin{array}{l}\text { Dehesa de } \\
\text { la Villa }\end{array}$ & $\begin{array}{l}\text { Majada- } \\
\text { honda }\end{array}$ & Toledo & $\begin{array}{l}\text { Dehesa de } \\
\text { Amaniel }\end{array}$ & Retiro & $\begin{array}{l}\text { Fuente } \\
\text { Umbría }\end{array}$ \\
\hline $\begin{array}{l}\text { Height growth in Puerta de Hierro, Madrid } \\
\left(\mathrm{cm} \mathrm{year}^{-1}\right)\end{array}$ & 100.0 & 63.0 & 60.8 & 89.3 & 90.0 & 70.5 & 51.7 \\
\hline Petiole length $(\mathrm{mm})$ & $\begin{array}{c}5.2 \\
(4.2-6.2)\end{array}$ & $\begin{array}{c}6.3 \\
(3.5-10.0)\end{array}$ & $\begin{array}{c}11.0 \\
(10-12.7)\end{array}$ & $\begin{array}{c}5.8 \\
(4.6-7.4)\end{array}$ & $\begin{array}{c}2.6 \\
(1.9-3.4)\end{array}$ & $\begin{array}{c}7.3 \\
(6.1-8.0)\end{array}$ & $\begin{array}{c}10.2 \\
(8.3-12.2)\end{array}$ \\
\hline Leaf basal asymmetry (mm) & $\begin{array}{c}1.6 \\
(1.1-1.9)\end{array}$ & $\begin{array}{c}2.9 \\
(2.0-3.8)\end{array}$ & $\begin{array}{c}3.8 \\
(2.0-4.8)\end{array}$ & $\begin{array}{c}1.3 \\
(0.7-2.4)\end{array}$ & $\begin{array}{c}1.3 \\
(0.8-1.8)\end{array}$ & $\begin{array}{c}1.2 \\
(0.3-1.7)\end{array}$ & $\begin{array}{c}3.1 \\
(2.2-4.2)\end{array}$ \\
\hline Maximum foliar length (mm) & $\begin{array}{c}53.7 \\
(43.5-65.1)\end{array}$ & $\begin{array}{c}55.4 \\
(44.0-70.0)\end{array}$ & $\begin{array}{c}50.4 \\
(46.7-53.6)\end{array}$ & $\begin{array}{c}47.0 \\
(35.6-71.5)\end{array}$ & $\begin{array}{c}38.5 \\
(36.2-39.6)\end{array}$ & $\begin{array}{c}71.4 \\
(63.9-79.4)\end{array}$ & $\begin{array}{c}75.9 \\
(69.8-85.9)\end{array}$ \\
\hline Maximum foliar width (mm) & $\begin{array}{c}33.8 \\
(30.0-38.6)\end{array}$ & $\begin{array}{c}35.6 \\
(28.0-45.0)\end{array}$ & $\begin{array}{c}28.8 \\
(25.5-30.6)\end{array}$ & $\begin{array}{c}26.6 \\
(19.6-35.2)\end{array}$ & $\begin{array}{c}29.7 \\
(27.3-33.0)\end{array}$ & $\begin{array}{c}42.2 \\
(36.4-48.9)\end{array}$ & $\begin{array}{c}44.9 \\
(39.3-48.7)\end{array}$ \\
\hline Tooth breadth (mm) & $\begin{array}{c}2.2 \\
(1.9-2.6)\end{array}$ & $\begin{array}{c}3.5 \\
(3.0-4.9)\end{array}$ & $\begin{array}{c}1.1 \\
(0.8-1.3)\end{array}$ & $\begin{array}{c}4.1 \\
(3.6-4.7)\end{array}$ & $\begin{array}{c}2.2 \\
(1.2-2.6)\end{array}$ & $\begin{array}{c}2.8 \\
(2.5-3.7)\end{array}$ & $\begin{array}{c}2.8 \\
(1.9-3.8)\end{array}$ \\
\hline Tooth depth (mm) & $\begin{array}{c}3.4 \\
(2.8-4.0)\end{array}$ & $\begin{array}{c}3.7 \\
(2.4-5.0)\end{array}$ & $\begin{array}{c}1.8 \\
(1.4-2.3)\end{array}$ & $\begin{array}{c}3.2 \\
(2.6-4.4)\end{array}$ & $\begin{array}{c}2.7 \\
(2.1-3.5)\end{array}$ & $\begin{array}{c}2.2 \\
(1.4-2.8)\end{array}$ & $\begin{array}{c}2.3 \\
(2.1-2.6)\end{array}$ \\
\hline Tooth length (mm) & $\begin{array}{c}4.2 \\
(3.8-4.4)\end{array}$ & $\begin{array}{c}4.6 \\
(4.0-5.1)\end{array}$ & $\begin{array}{c}2.3 \\
(1.9-2.9)\end{array}$ & $\begin{array}{c}5.4 \\
(4.8-5.9)\end{array}$ & $\begin{array}{c}3.5 \\
(2.8-4.2)\end{array}$ & $\begin{array}{c}2.9 \\
(2.1-3.8)\end{array}$ & $\begin{array}{c}3.0 \\
(2.2-4.1)\end{array}$ \\
\hline Teeth per leaf $(\mathrm{N})$ & $\begin{array}{c}38 \\
(35-42)\end{array}$ & $\begin{array}{c}44 \\
(30-64)\end{array}$ & $\begin{array}{c}54 \\
(52-57)\end{array}$ & $\begin{array}{c}30.0 \\
(28-33)\end{array}$ & $\begin{array}{c}33 \\
(31-35)\end{array}$ & $\begin{array}{c}49 \\
(45-53)\end{array}$ & $\begin{array}{c}32 \\
(28-34)\end{array}$ \\
\hline Pairs of secondary nerves $(\mathrm{N})$ & $\begin{array}{c}10 \\
(9-11)\end{array}$ & $\begin{array}{c}10 \\
(9-12)\end{array}$ & $\begin{array}{c}12 \\
(11-12)\end{array}$ & $\begin{array}{c}8.8 \\
(8-10)\end{array}$ & $\begin{array}{c}9.3 \\
(8-10)\end{array}$ & $\begin{array}{c}13 \\
(12-15)\end{array}$ & $\begin{array}{c}12 \\
(11-13)\end{array}$ \\
\hline Leaf serration & Double & Double & Simple & Double & Triple & Double & Double \\
\hline Presence of corky tissue & No & No & No & No & Yes & No & Yes \\
\hline Foliar density & Medium & High & High & Medium & High & High & Medium \\
\hline Branching & Erect & Erect & Erect & Erect & Spreading & Erect & Erect \\
\hline Crow & Spindle & Spindle & Globular & Irregular & Irregular & Globular & Irregular \\
\hline Ornamental value $^{a}$ & 4.5 & 4.1 & 4.3 & 2.9 & 3.0 & 4.0 & 3 \\
\hline
\end{tabular}

sible emerging races of the pathogen under different climate conditions need to be as sessed. Before the clones are used in other areas, it would be advisable to establish adaptation trials to allow quantification of their susceptibility to drought, frosts, flooding and pests such as bark beetles, Hemiptera and the elm leaf-beetle, Galerucella luteola.

DED fungi have caused mortality not only of large elm groves of $U$. minor in Spain, but also of many centuries-old elms that had decorated parks, gardens and town and city squares. Therefore, although registration of the seven clones was focused on forest use, recovery of $U$. minor for urban use was also a key objective of the programme. To this end, distinct morphological features and appreciation of the ornamental value of the seven clones are shown in Tab. 3, Fig. 3 and Fig. 4. Three of the clones ("Ademuz", "Toledo" and "Dehesa de Amaniel") showed growth rates very similar to "Sapporo Autumn Gold", which grows $94.5 \mathrm{~cm}$ in height per year in Puerta de Hierro. Foliar density of the seven clones was medium or high compared to "Sapporo Autumn Gold", which shows low or medium-low density in Madrid. The "Ademuz" and "Majadahonda" clones have the highest ornamental scores and are promising trees for use in urban environments and tree breeding for ornamental quality. These two genotypes showed a later bud burst phenology than the other $U$. minor clones (Fig. 5), which demonstrates probable suitability to areas with late frost events. The earlier phenology in "Sapporo Autumn Gold" (U. pumila $\times$ U. davidiana var. japonica hybrid) than in the Spanish elms is due to its Asian background. Asian elms exhibit earlier bud burst phenology than European elms (Ghelardini et al. 2010).

The results of the genetic characterization of the seven clones are shown in Tab. 4. This description is intended to guarantee the traceability of the plant material during use, especially if clones are commercialized in the near future. From the experience of the Spanish elm breeding programme, the high level of polymorphism obtained with the microsatellites selected allows rigorous identification of each clone.

Tab. 4 - Genetic characterisation of the seven Ulmus minor clones, showing alleles for the two chloroplast and 12 nuclear microsatellites used. (a): not amplified.

\begin{tabular}{|c|c|c|c|c|c|c|c|c|}
\hline \multirow[b]{2}{*}{$\begin{array}{l}\text { Orga- } \\
\text { nelle }\end{array}$} & \multirow[b]{2}{*}{$\begin{array}{l}\text { DNA } \\
\text { marker }\end{array}$} & \multicolumn{7}{|c|}{ Clone } \\
\hline & & Ademuz & $\begin{array}{c}\text { Dehesa } \\
\text { de la } \\
\text { Villa }\end{array}$ & $\begin{array}{c}\text { Majada- } \\
\text { honda }\end{array}$ & Toledo & $\begin{array}{c}\text { Dehesa } \\
\text { de } \\
\text { Amaniel }\end{array}$ & Retiro & $\begin{array}{c}\text { Fuente } \\
\text { Umbría }\end{array}$ \\
\hline \multirow{2}{*}{$\begin{array}{l}\text { Chloro- } \\
\text { plast }\end{array}$} & ccmp2 & 237 & 236 & 236 & 215 & 236 & 216 & 215 \\
\hline & SFm & 278 & 278 & 278 & 297 & 278 & 297 & 297 \\
\hline \multirow[t]{12}{*}{ Nuclear } & Ulm 2 & 102108 & $102 \quad 102$ & 106108 & 102102 & 106108 & 108108 & $102 \quad 102$ \\
\hline & Ulm 3 & 161176 & $176 \quad 176$ & 176180 & 161180 & 176176 & 176180 & $\begin{array}{ll}161 & 161\end{array}$ \\
\hline & Ulm 8 & 196196 & 196196 & 194196 & 194198 & 196196 & 196196 & 194194 \\
\hline & UR 123 & $250 \quad 250$ & $252 \quad 254$ & $250 \quad 254$ & $242 \quad 250$ & $250 \quad 254$ & $252 \quad 254$ & $255 \quad 259$ \\
\hline & UR 141 & $\begin{array}{ll}150 & 152\end{array}$ & $152 \quad 160$ & 152158 & $152 \quad 152$ & 158158 & 158158 & $152 \quad 158$ \\
\hline & UR 153 & 178190 & $184 \quad 188$ & $188 \quad 188$ & 188188 & $178 \quad 188$ & 186188 & $178 \quad 190$ \\
\hline & UR 158 & 195195 & 179195 & 195195 & 179179 & 179199 & 179179 & $\begin{array}{ll}179 & 179\end{array}$ \\
\hline & UR 159 & 258260 & $\begin{array}{lll}260 & 278\end{array}$ & $278 \quad 278$ & 260278 & $278 \quad 280$ & $278 \quad 278$ & $258 \quad 258$ \\
\hline & Ulm 1-98 & $151 \quad 151$ & $151 \quad 151$ & $151 \quad 151$ & $151 \quad 151$ & $151 \quad 151$ & $151 \quad 151$ & 151154 \\
\hline & Ulm 1-165 & 204204 & 146146 & 164164 & 130148 & 204204 & 156156 & 160160 \\
\hline & & $90 \quad 90$ & $90 \quad 90$ & $90 \quad 90$ & - & $90 \quad 90$ & $82 \quad 94$ & $90 \quad 90$ \\
\hline & Ulm 2-20 & $-^{\mathrm{a}}$ & 184202 & 172206 & 206220 & 186202 & $180 \quad 184$ & $220 \quad 220$ \\
\hline
\end{tabular}



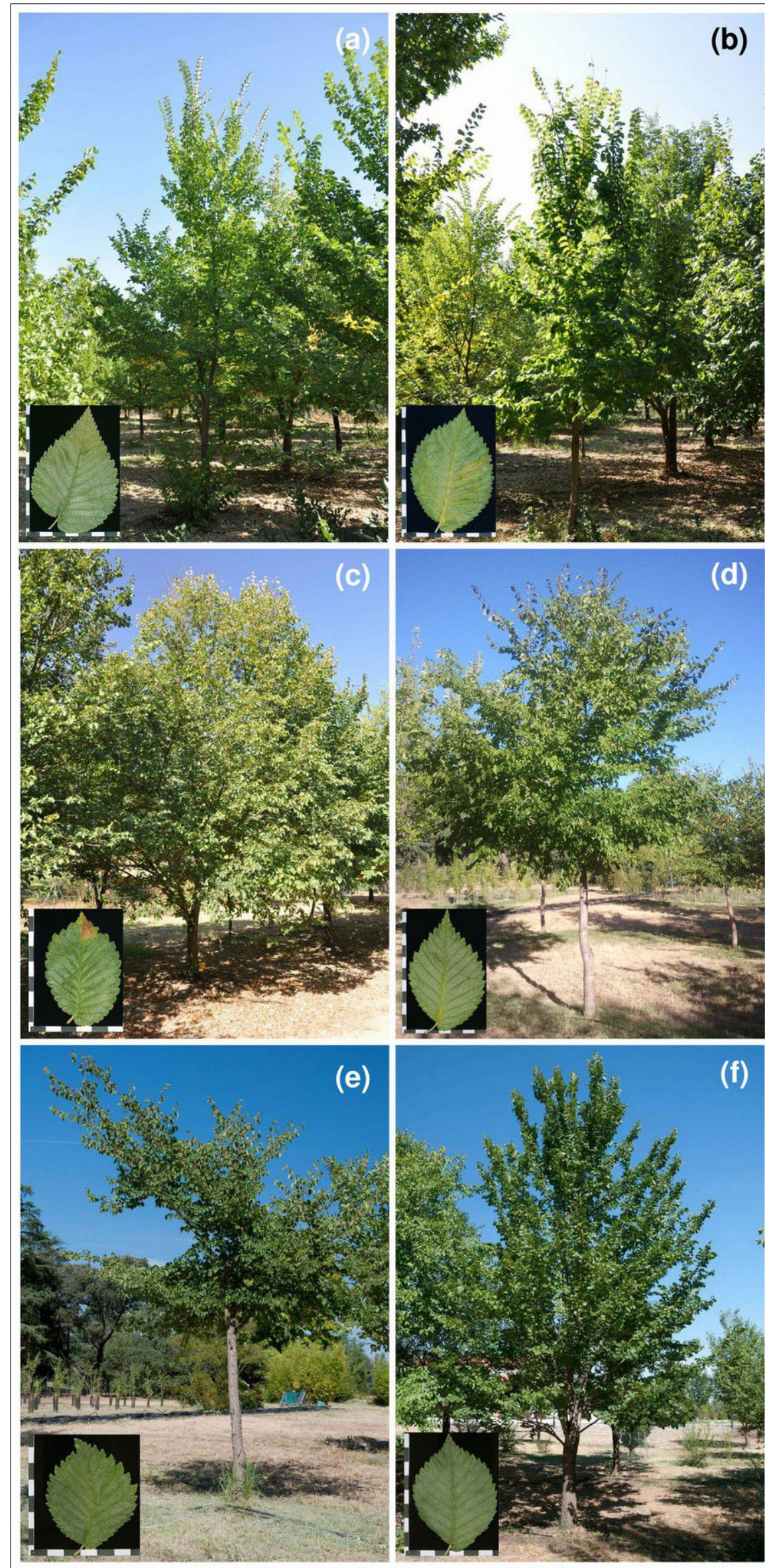

(b)

Fig. 3 - Registered Ulmus minor clones grown in the clonal bank of Puerta de Hierro Forest Breeding Center, Madrid. (a) "Ademuz": (b) "Dehesa de la Villa"; (c) "Majadahonda"; (d) "Toledo"; (e) "Dehesa de Amaniel"; and (f) "Retiro" clones met the requirements to be registered as "qualified forest reproductive material" in Spain. Scale bars in leaf close-ups $=1 \mathrm{~cm}$. 
Fig. 4 - Registered "Fuente Umbría" clone grown in the clonal bank of Puerta de Hierro Forest Breeding Center (Madrid). This Ulmus minor clone met the requirements to be registered as "controlled forest reproductive material" in Spain. Scale bars in leaf close-up $=1 \mathrm{~cm}$.

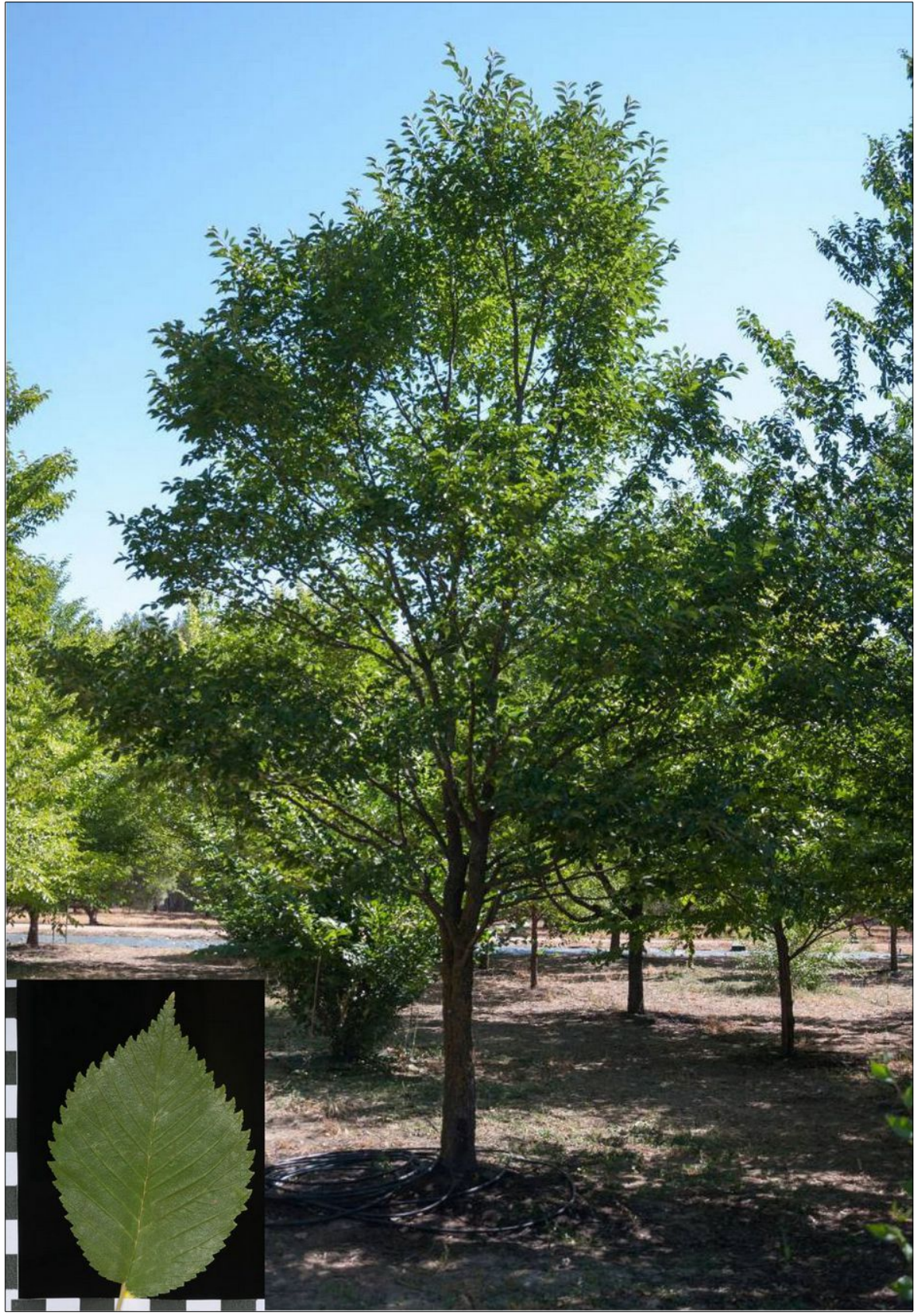

native elms. Elm tolerance to $O$. novo-ulmi has been shown to be inheritable (Townsend 2000, Guries \& Smalley 2000, Solla et al. 2014, Venturas et al. 2014) and polygenic (quantitative) in nature (Aoun et al. 2010). It also depends on constitutive and inducible mechanisms of defence (e.g., Martín et al.
2007, 2008b, 2013). In addition, the defense mechanisms of elms to O. novo-ulmi seem to differ between genotypes. This is the case of some anatomical features of the xylem associated with pathogen dispersal, such as pit and vessel size (Martín et al. 2009, 2013). When more resistance mechanisms are gato increase the genetic diversity of toleran

Fig. 5 - Leaf phenology in 2011 of the seven registered Ulmus minor clones and the "Sapporo Autumn Gold" control clone in Puerta de Hierro Forest Breeding Centre, Madrid.

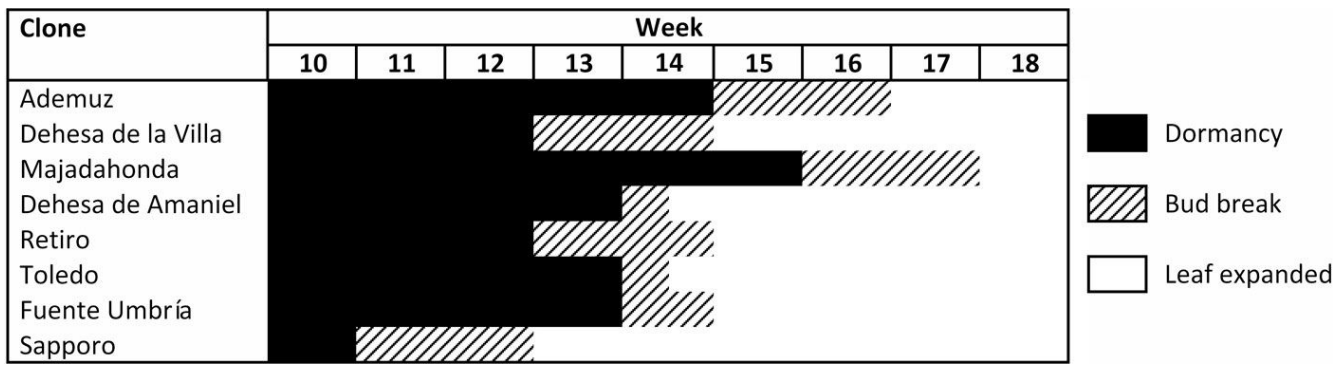


thered in the same genotype, the chances of overcoming an infection are likely to increase. Thus it would be desirable to perform controlled crossings between genotypes that express different, and preferably complementary, defense mechanisms. If multiple resistance layers act jointly and in a complementary fashion, the influence of environmental factors in tree tolerance to $O$. novoulmi would probably be lower. The possibility of any emerging variant or pathogen mutation overcoming the resistance mechanisms would also decrease. Understanding the genetic basis of elm tolerance to $O$. novo-ulmi is our second main research challenge.

To broaden the genetic base of tolerant native elms, the Spanish programme has grown 1400 seedlings from controlled $F_{1}$ crossings between the seven $U$. minor clones. In 2016, when seedlings are four years old, they will be inoculated with $O$. novo-ulmi. The tolerance of new genotypes from different provenances in Spain to $O$. novo-ulmi will be assessed through clonal replicates $(N \geq 6)$ in the near future. Most of these genotypes have shown high tolerance levels when individually tested as seedlings. With this material, the Spanish programme expects to substantially increase the number of $U$. minor clones tolerant to $O$. novo-ulmi.

\section{Conclusions}

Although tree selection, trial establishment and breeding cycles require a major investment in time and effort, breeding programmes are the most reliable option for recovery of native elm populations. Results reported here show that selection of tolerant native $U$. minor genotypes is possible. The seven clones registered as forest reproductive material have shown high tolerance to DED in Spain. Their form and foliage are attractive and they are fast-growing trees. Longitudinal monitoring of the performance of the selected clones under different environments will make it possible to determine the suitable environmental range of each clone. New elm varieties likely to show low wilting values after $O$. novo-ulmi inoculation will be obtained in the next few years.

\section{Acknowledgements}

This paper is dedicated to Margarita $\mathrm{Bu}$ rón, who spent the last ten years of her life working on the conservation and breeding of Spanish elms.

The authors are grateful to everyone who has participated in the Spanish elm breeding programme during its 27 years of existence. We would also like to express our gratitude to the Dutch and Italian elm breeding programmes and the participants in the EU Project RESGEN CT96-78 for sharing their knowledge and materials. The programme is funded by the Spanish Directorate-General of Rural Development and Forestry Policy
(Dirección General de Desarrollo Rural y Politica Forestal) and the Spanish Ministry of Agriculture, Food and Environmental Affairs (Ministerio de Agricultura, Alimentación y Medio Ambiente).

\section{References}

Allué-Andrade JL (1990). Atlas fitoclimático de España. Taxonomías [Phytoclimatic atlas of Spain. Taxonomy]. Instituto Nacional de Investigaciones Agrarias, Ministerio de Agricultura Pesca y Alimentación, Madrid, Spain. [in Spanish] Aoun M, Jacobi V, Boyle B, Bernier L (2010). Identification and monitoring of Ulmus americana transcripts during in vitro interactions with the Dutch elm disease pathogen Ophiostoma novo-ulmi. Physiological and Molecular Plant $\mathrm{Pa}$ thology 74: 254-266. - doi: 10.1016/j.pmpp.20 10.04.003

Brasier CM, Kirk SA (2010). Rapid emergence of hybrids between two subspecies of Ophiostoma novo-ulmi with a high level of pathogenic fitness. Plant Pathology 59: 186-199. - doi: 10.111 1/j.1365-3059.2009.02157.x

Buiteveld J, van der Werf B, Hiemstra JA (2014). Comparison of commercial elm cultivars and promising unreleased Dutch clones for resistance to Ophiostoma novo-ulmi. iForest (early view). doi: 10.3832/ifor1209-008

Cogolludo-Agustín MA, Agúndez D, Gil L (2000). Identification of native and hybrid elms in Spain using isozyme gene markers. Heredity 85: 157-166. - doi: 10.1046/j.1365-2540.2000. 00740.x

Collada C, Fuentes-Utrilla P, Gil L, Cervera MT (2004). Characterization of microsatellite loci in Ulmus minor Miller and cross-amplification in U. glabra Hudson and U. laevis Pall. Molecular Ecology Notes 4: 731-732. - doi: 10.1111/j.14 71-8286.2004.00798.x

Ghelardini L, Santini A, Black-Samuelsson S, Myking T, Falusi M (2010). Bud dormancy release in elm (Ulmus spp.) clones - a case study of photoperiod and temperature responses. Tree Physiology 30: 264-74. - doi: 10.1093/treephys/ tpp 110

Gil L, Fuentes-Utrilla P, Soto A, Cervera MT, Collada C (2004). English elm (Ulmus procera) is a 2000-year-old Roman clone. Nature 431: 1053. - doi: 10.1038/4311053a

Guries RP, Smalley EB (2000). Once and future elms: classical and molecular approaches to Dutch elm disease resistance. In: "The elms: breeding, conservation and disease management" (Dunn CP ed), Kluwer Academic Publishers, Boston, USA, pp. 231-248.

Heybroek HM (1993). The Dutch elm breeding program. In: "Dutch Elm Disease Research: Cellular and Molecular Approaches" (Sticklen MB, Sherald JL eds). Springer Verlag, New York, USA, pp. 16-25.

Iglesias S (2005). Normativa de comercialización de material forestal de reproducción [Marketing regulations for forest reproductive material]. In: "Manual para la Comercialización y Producción de Semillas y Plantas Forestales. Materiales de
Base y Reproducción" (Alía A, Alba N, Agúndez D, Iglesias S eds), Organismo Autónomo Parques Nacionales, Ministerio de Medio Ambiente, Madrid, Spain, pp. 39-58. [in Spanish]

Ipinza R (1990). Algunos aspectos relevantes sobre la taxonomía de los olmos ibéricos [Some relevant aspects of the taxonomy of Iberian elms]. In: "Los olmos y la grafiosis en España" (Gil L ed). ICONA, Madrid, pp. 69-98. [in Spanish]

Jeffers J, Richens R (1970). Multivariate analysis of the English elm population. Silvae Genetica 19: 31-38. [online] URL: http://sauerlaender-verlag.com/fileadmin/content/dokument/archiv/silvaegenetica/19 1970/19-1-31.pdf

Martín JA, Solla A, Woodward S, Gil L (2005). Fourier transform-infrared spectroscopy as a new method for evaluating host resistance in the Dutch elm disease complex. Tree Physiology 25: 1331-1338. - doi: 10.1093/treephys/25.10.1331

Martín JA, Solla A, Woodward S, Gil L (2007). Detection of differential changes in lignin composition of elm xylem tissues inoculated with Ophiostoma novo-ulmi using Fourier transform infrared spectroscopy. Forest Pathology 37: 187 191. - doi: 10.1111/j.1439-0329.2007.00495.x Martín JA, Solla A, Coimbra MA, Gil L (2008a). Metabolic fingerprinting allows discrimination between Ulmus pumila and U. minor and between $U$. minor clones of different susceptibility to Dutch elm disease. Forest Pathology 38: 244256. - doi: 10.1111/j.1439-0329.2007.0054 2.x Martín JA, Solla A, Domingues MR, Coimbra MA, Gil L (2008b). Exogenous phenol increase resistance of Ulmus minor to Dutch elm disease through formation of suberin-like compounds on xylem tissues. Environmental and Experimental Botany 64: 97-104. - doi: 10.1016/j.envexpbot. 2008.05.004

Martín JA, Solla A, Esteban LG, de Palacios P, Gil L (2009). Bordered pit and ray morphology involvement in elm resistance to Ophiostoma novo-ulmi. Canadian Journal of Forest Research 39: 420-429. - doi: 10.1139/X08-183

Martín JA, Solla A, Gil L, Garcia-Vallejo MC (2010a). Phenological and histochemical changes of Ulmus minor due to root absorption of phenol: implications for resistance to DED. Environmental and Experimental Botany 69: 175182. - doi: 10.1016/j.envexpbot.2010.04.001

Martín JA, Solla A, Witzell J, Gil L, GarcíaVallejo MC (2010b). Antifungal effect and reduction of Ulmus minor symptoms to Ophiostoma novo-ulmi by carvacrol and salicylic acid. European Journal of Plant Pathology 127: 21-32. - doi: 10.1007/s10658-009-9567-3

Martín JA, Solla A, García-Vallejo MC, Gil L (2012). Chemical changes in Ulmus minor xylem tissue after salicylic acid or carvacrol treatments are associated with enhanced resistance to Ophiostoma novo-ulmi. Phytochemistry 83: 104109. - doi: 10.1016/j.phytochem.2012.07.017

Martín JA, Solla A, Ruiz-Villar M, Gil L (2013). Vessel length and conductivity of Ulmus branches: ontogenetic changes and relation to resistance to Dutch elm disease. Trees 27: 1239- 
1248. - doi: 10.1007/s00468-013-0872-2

Mittempergher L, Santini A (2004). The history of elm breeding. Forest Systems 13: 161-177. [online] URL: http://revistas.inia.es/index.php/fs/ article/view/821

Richens RH (1955). Studies on Ulmus. I. The range of variation of East Anglian elms. Watsonia 3: 138-153. [online] URL: http://www. archive.bsbi.org.uk/Wats3p138.pdf

Santini A, Fagnani A, Ferrini F, Mittempergher L, Brunetti M, Crivellaro A, Macchioni N (2004). Elm breeding for DED resistance: the Italian clones and their wood properties. Forest Systems 13: 179-184. [online] URL: http://revistas.inia.es/index.php/fs/article/view/822

Santini A, Fagnani A, Ferrini F, Ghelardini L, Mittempergher L (2005). Variation among Italian and French elm clones in their response to Ophiostoma novo-ulmi inoculation. Forest $\mathrm{Pa}$ thology 35: 183-193. - doi: 10.1111/j.1439-03 29.2005.00401.x

Santini A, Pecori F, Pepori A, Brookes A (2011). "Morfeo" elm: a new variety resistant to Dutch elm disease. Forest Pathology 42:171-176. - doi 10.1111/j.1439-0329.2011.00737.x

Smalley EB (1963). Seasonal fluctuations in susceptibility of young elm seedlings to Dutch elm disease. Phytopathology 53: 846-853.

Smalley EB, Guries RP (2000). Asian elms: sources of disease and insect resistance. In: "The elms: breeding, conservation and disease management" (Dunn CP ed). Kluwer Academic Publishers, Boston, USA, pp. 215-230.

Smalley EB, Lester DT (1973). "Sapporo autumn gold" elm. Horticultural Science 8: 514-515.

Solla A, Gil L (2002). Influence of water stress on Dutch elm disease symptoms in Ulmus minor Miller. Canadian Journal of Botany 80: 810-817. - doi: 10.1139/b02-067

Solla A, Gil L (2003). Evaluating Verticillium dahliae for biological control of Ophiostoma novo-ulmi in Ulmus minor. Plant Pathology 52: 579-585. - doi: 10.1046/j.1365-3059.2003.00 921.x

Solla A, Burón M, Iglesias S, Gil L (2000). Spanish program for the conservation and breeding of elms against DED. In: "The Elms: Breeding, Conservation and Disease Management" (Dunn CP ed), Kluwer Academic Publishers, Boston, pp. 295-303.

Solla A, Bohnens J, Collin E, Diamandis S, Franke A, Gil L, Burón M, Santini A, Mittempergher L, Pinon J, van den Broeck A (2005a). Screening European elms for resistance to Ophiostoma novo-ulmi. Forest Science 51: 134141.

Solla A, Martín JA, Corral P, Gil L (2005b). Seasonal changes in wood formation of Ulmus pumila and $U$. minor and its relation with Dutch elm disease. New Phytologist 166:1025-1034. doi: 10.1111/j.1469-8137.2005.01384.x

Solla A, Martín JA, Ouellette G, Gil L (2005c). Influence of plant age on symptom development in Ulmus minor following inoculation by Ophiostoma novo-ulmi. Plant Disease 89:1035-1040. doi: 10.1094/PD-89-1035

Solla A, López-Almansa JC, Martín JA, Gil L (2014). Genetic variation and heritability estimates of Ulmus minor and U. pumila hybrids for budburst, growth and tolerance to Ophiostoma novo-ulmi. iForest [submitted].

Sutherland ML, Pearson S, Brasier CM (1997). The influence of temperature and light on defoliation levels of elm by Dutch elm disease. Phytopathology 87: $576 \quad-581 . \quad$ - doi: 10.1094/PHYTO.1997.87.6.576

Tchernoff V (1965). Methods for screening and for the rapid selection of elms for resistance to Dutch elm disease. Acta Botanica Neerlandica 14: 409-452. - doi: 10.1111/j.1438-8677.1965.tb 00204.x

Townsend AM (2000). USDA genetic research on elms. In: "The Elms: Breeding, Conservation and Disease Management" (Dunn CP ed). Kluwer Academic Publishers, Boston, USA, pp. 271278.

Venturas M, López R, Martín JA, Gascó A, Gil L (2014). Heritability of Ulmus minor resistance to Dutch elm disease and its relationship to vessel size, but not to xylem vulnerability to drought. Plant Pathology - doi: 10.1111/ppa.12115.

Vivas M, Martín JA, Gil L, Solla A (2012). Evaluating methyl jasmonate for induction of resistance to Fusarium oxysporum, F. circinatum and Ophiostoma novo-ulmi. Forest Systems 21: 289-299. - doi: 10.5424/fs/2012212-02172

Webber JF (2000). Insect vector behavior and the evolution of Dutch elm disease. In: "The Elms: Breeding, Conservation and Disease Management" (Dunn CP ed). Kluwer Academic Publishers, Boston, MS, USA, pp. 47-60.

Weising K, Gardner RC (1999). A set of conserved PCR primers for the analysis of simple sequence repeat polymorphisms in chloroplast genomes of dicotyledonous angiosperms. Genome 42: 9-19. - doi: 10.1139/g98-104

Whiteley RE, Black-Samuelsson S, Clapham D (2003). Development of microsatellite markers for the European white elm (Ulmus laevis Pall.) and cross-species amplification within the genus Ulmus. Molecular Ecology Notes 3: 598-600. doi: 10.1046/j.1471-8286.2003.00525.x

Zalapa JE, Brunet J, Guries RP (2008). Isolation and characterization of microsatellite markers for red elm (Ulmus rubra Muhl.) and cross-species amplification with Siberian elm (Ulmus pumila L.). Molecular Ecology Resources 8: 109-112. doi: $10.1111 / \mathrm{j} .1471-8286.2007 .01805 . \mathrm{x}$ 